than the elite or working classes, the middle class and its interest in connections, associations, links, and networks are an ideal subject for scholars interested in transnational approaches to the past. Because it succeeds in offering specific examples of middle-class formation within a broader transnational framework, scholars will find this collection valuable for promoting classroom discussion as well as sparking new approaches to their own research.

Jonathan Daniel Wells

Temple University

\title{
Anna J. Willow, Strong Hearts, Native Lands: Anti-Clearcutting Activism at Grassy Narrows First Nation (Winnipeg, MB: University of Manitoba Press, 2012).
}

Anna J. Willow opens with movement: on 3 December 2003, “three young members of Grassy Narrows First Nation positioned a falling tree across a snow-covered logging road" (1). Thus begins the Grassy Narrows blockade, a communitydirected campaign to stop unregulated corporate logging by Abitibi-Consolidated in Grassy Narrows Traditional Land Use Area. Willow argues that the act of a blockade represented an assertion of treaty rights including, but by no means limited to, the "right to pursue their [Anishinaabe] avocations of hunting and fishing." She further argues that the placement of the blockade became a site of cultural revitalization. In short, Strong Hearts, Native Lands makes the case that environmental issues are intertwined with political and social issues. The fight to save Whiskey Jack Forest cannot be separated from the fight to uphold Treaty $\# 3$, to receive recognition as a sovereign nation, and ultimately to protect the Anishinaabe way of life from unrestrained corporate development on Anishinaabe lands.

Willow divides her text into two sections. The first three chapters provide context. In Chapter 1, Willow suggests that land-based subsistence has become a marker of cultural identity. Harvesting practices that were once "a way of life" now allow Anishinaabe peoples to define themselves against mainstream society (36). Willow positions the blockade as an attempt to maintain "a deeply symbolic way of life" by preserving territory required for land-based subsistence (35). Chapter 2 explores the cultural and political influences on the Grassy Narrows blockade while Chapter 3 focuses on material drivers. Here, Willow illustrates the environmental realities of reservation life - from hydroelectric flooding to mercury poisoning -that spurred direct action.

The second section (Chapters $4-8$ ) discusses the blockade's beginnings, its culture, and its preservation. Chapter 4 introduces the Grassy Narrows Environmental Group (GNEG) and their initial attempts to combat clearcutting. Chapters 5 and 6 examine the establishment of the blockade at Slant Lake. 
Willow illustrates the growing tensions between Grassy Narrows' activists and Abitibi-Consolidated workers over land use. In addition to becoming a site of conflict, Slant Lake became a "place for healing" (132). Willow suggests that visitors and participants alike could (re)learn cultural practices and activities on-site. Chapter 7 reveals tensions between Grassy Narrows Environmental Group and Grassy Narrows Band Council. Full-time occupation of Slant Lake declined as the elected band leadership entered into talks with Abitibi-Consolidated and the Ontario Ministry of Natural Resources. Willow concludes with a discussion of Grassy Narrows' growing network of external supporters. Chapter 8 explores the legacy of Grassy Narrows' blockade. Finally, Willow suggests that Grassy Narrows' inspired other Anishinaabe peoples to defend their treaty rights by looking at other instances of direct action on Mishkeegogamanag First Nation.

Although Willow's narrative is multifaceted and engaging, pinpointing her evidence is not an easy task. Willow relies heavily on participant observation. In spring 2003, Willow spent one month camping at Slant Lake. In spring 2004, Willow returned to the site to undertake "eleven months of full-time fieldwork" (10). In her footnotes, Willow suggests that she drew "primarily on oral history shared by individuals at Grassy Narrows First Nations between 2003 and 2005" (213). And yet, she reveals very little about her informants. Consequently, one can learn more about Willow's sources from her "Acknowledgements" page than from her citations or bibliography.

Willow's sparing use of citations raises questions about how Willow might be privileging GNEG on the one hand and forming her critique of Band Council on the other. Willow suggests that GNEG operated according to "informal, egalitarian principles," likening it to traditional Anishinaabe power structures. She further suggests that one of GNEG's core members was "a top contender for the role of customary chief" (86). Willow uses GNEG's ties to "traditional" power to criticize the fact that some activists were excluded from talks between Band Council and Abitibi-Consolidated (88). Her critique, however, fails to acknowledge that traditional leadership was largely merit-based. As Anton Treuer explained, "The Ojibwe word for leadership - ogimmaawiwin - literally means 'to be esteemed' or 'held to high principle."'1 While power may have been hereditary, individuals could assume leadership positions through community service. True, band council may have originated with the Indian Act - but, do band council elections today not reflect merit? Willow places too much importance on hereditary leadership and almost none on merit. But, both were key factors in determining community power.

Further, Willow downplays band council decisions that suggest "egalitarian" thinking - particularly, the decision to postpone talks with AbitibiConsolidated until community consensus could be reached (162). Instances where Chief Simon Fobister acted in concert with GNEG activists are buried in the footnotes $(220, \mathrm{n} 1)$. Willow uses blood and connections to the Indian Act to 
question the band council's legitimacy. But, what is it that makes GNEG more representative? From what does GNEG derive merit? What legitimates the voice of Willow's "three sisters from Grassy Narrows" (184)? While community tension was clearly evident, Willow favours scrutinizing community dynamics while rarely questioning what she views as "traditional" power.

One of Willow's central interests is in cultural revitalization. She makes the threat of clearcutting to cultural practices clear, but the material consequences are not always explicit. She says little about how clearcutting can destroy animal habitat, reduce trappers' access to trap lines, or destroy traps themselves. Clearcutting creates real material risks, but Willow's analysis rarely goes farther than the abstraction of protecting "tradition."

In spite of its shortcomings, Strong Hearts, Native Lands contributes to our understanding of the environment as a battleground for social justice. It is a celebration of grassroots activism. It is an empowering story about the assertion of Indigenous rights. I recommend Willow's book for use in the undergraduate classroom as it provides a clear example of Indigenous protest in Canada. Designed, in part, to inspire the youth of Grassy Narrows, Strong Hearts, Native Lands is a poignant reminder that three people and a fallen tree can launch a defense of ten thousand square kilometres of land and the treaty rights guaranteed therein.

\section{NOTES}

1 Anton Treuer, The Assassination of Hold in the Day (St. Paul, MN: Borealis Books, 2011), 14.

Brittany Luby

York University

\section{Sotiris Rizas, The Rise of the Left in Southern Europe: Anglo-American Responses (London: Pickering and Chatto, 2012).}

From the late nineteenth century Mediterranean Europe showed markedly different patterns of working-class formation, labour militancy, party building, and socialist institutionalisation than either the Central European and Scandinavian heartlands of social democracy or the mixed labour and peasant territories of the Balkans and Eastern Europe. While not reducible to the contrasting levels of economic development and industrialization, these differences were clearly connected to regional sociologies of development, because agrarian radicalisms of various kinds - for example the rural strengths of anarcho-syndicalism in Spain, or the vital role of the agricultural labourers of the Po Valley in northern Italy centrally shaped the Lefts of their respective countries. Coercive labor regimes in town and country, sharp inequalities of political access, and high levels of state 